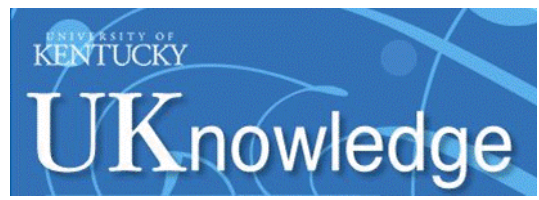

University of Kentucky

UKnowledge

Biosystems and Agricultural Engineering Faculty Publications

\title{
Application of Hyperspectral Imaging and Acoustic Emission Techniques for Apple Quality Prediction
}

\author{
Nader Ekramirad \\ University of Kentucky \\ Ahmed Rady \\ University of Kentucky \\ Akinbode A. Adedeji \\ University of Kentucky, akinbode.adedeji@uky.edu \\ Reza Alimardani \\ University of Tehran, Iran
}

Follow this and additional works at: https://uknowledge.uky.edu/bae_facpub

Part of the Agriculture Commons, and the Bioresource and Agricultural Engineering Commons Right click to open a feedback form in a new tab to let us know how this document benefits you.

\section{Repository Citation}

Ekramirad, Nader; Rady, Ahmed; Adedeji, Akinbode A.; and Alimardani, Reza, "Application of Hyperspectral Imaging and Acoustic Emission Techniques for Apple Quality Prediction" (2017). Biosystems and Agricultural Engineering Faculty Publications. 213.

https://uknowledge.uky.edu/bae_facpub/213

This Article is brought to you for free and open access by the Biosystems and Agricultural Engineering at UKnowledge. It has been accepted for inclusion in Biosystems and Agricultural Engineering Faculty Publications by an authorized administrator of UKnowledge. For more information, please contact UKnowledge@lsv.uky.edu. 


\title{
Application of Hyperspectral Imaging and Acoustic Emission Techniques for Apple Quality Prediction
}

\author{
Digital Object Identifier (DOI) \\ https://doi.org/10.13031/trans.12184 \\ Notes/Citation Information \\ Published in Transactions of the ASABE, v. 60, issue 4, p. 1391-1401. \\ (C) 2017 American Society of Agricultural and Biological Engineers
}

The copyright holder has granted the permission for posting the article here. 


\title{
APPLICATION OF HYPERSPECTRAL IMAGING AND ACOUSTIC EMISSION TECHNIQUES FOR APPLE QUALITY PREDICTION
}

\author{
N. Ekramirad, A. Rady, A. A. Adedeji, R. Alimardani
}

\begin{abstract}
There is a growing demand for developing effective non-destructive quality assessment methods with quick response, high accuracy, and low cost for fresh fruits. In this study, hyperspectral reflectance imaging (400 to $1000 \mathrm{~nm}$ ) and acoustic emission (AE) tests were applied to 'GoldRush' apples (total number, $n=180$ ) to predict fruit firmness, total soluble solids (TSS), and surface color parameters $\left(L^{*}, a^{*}, b^{*}\right)$ during an eight-week storage period. Partial least squares $(P L S)$ regression, least squares support vector machine (LS-SVM), and multivariate linear regression (MLR) methods were used to establish models to predict the quality attributes of the apples. The results showed that hyperspectral imaging (HSI) could accurately predict all the attributes except TSS, while the AE method was capable of predicting fruit firmness, $b^{*}$ color index, and TSS. Overall, HSI regression using PLS had better comprehensive ability for predicting firmness, TSS, and color parameters $\left(L^{*}, a^{*}, b^{*}\right)$ than $A E$, with correlation coefficients of prediction $\left(r_{p}\right)$ of $0.92,0.41,0.83,0.87$, and 0.94 and root mean square errors of prediction (RMSEP) of $4.32(\mathrm{~N}), 1.78$ ( ${ }^{\circ}$ Brix), 3.41, 2.28, and 4.29, respectively, while AE regression using $L S$-SVM gave $r_{p}$ values of $0.88,0.74,0.34,0.37$, and 0.81 and RMSEP values of $4.26(\mathrm{~N}), 0.64\left({ }^{\circ} \mathrm{Brix}\right)$, $4.69,1.8$, and 5.17 for firmness, TSS, and color parameters $\left(L^{*}, a^{*}, b^{*}\right)$, respectively. The results show the potential of these two non-destructive methods for predicting some of the quality attributes of apples.
\end{abstract}

Keywords. Apple, Acoustic emission, Fruit quality, Hyperspectral imaging, Regression model.

A pples are among the most widely cultivated tree fruits worldwide, with an annual production of 80.8 million metric tons valued at nearly $\$ 31.9$ billion in 2013, and they are estimated to be the second most consumed fruit after oranges (FAOSTAT, 2013). Meanwhile, consumers are demanding higher internal and external fruit qualities, such as ripeness, firmness, total soluble solids (TSS), and color. Apples are generally sorted manually or automatically on the basis of size, color, and surface defects (Lu and Peng, 2007). Furthermore, the internal quality traits that influence consumer acceptance and price are still evaluated at small scale with conventional destructive tests, which are either subjective or time-consuming, so there is a need for the development of non-destructive methods for the inspection and classification of apples' internal and external attributes, accurately and rapidly,

Submitted for review in November 2016 as manuscript number PRS 12184; approved for publication by the Processing Systems Community of ASABE in May 2017.

The authors are Nader Ekramirad, Visiting Scholar, Department of Biosystems and Agricultural Engineering, University of Kentucky, Lexington, Kentucky, and Research Assistant, Department of Mechanical Engineering of Agricultural Machinery, University of Tehran, Karaj, Iran; Ahmed Rady, ASABE Member, Post-Doctoral Research Associate, Department of Biosystems and Agricultural Engineering, University of Kentucky, Lexington, Kentucky, and Lecturer, Department of Biosystems and Agricultural Engineering, Alexandria University, Alexandria, Egypt; Akinbode A. Adedeji, ASABE Member, Assistant Professor, Department of Biosystems and Agricultural Engineering, University of Kentucky, Lexington, Kentucky; Reza Alimardani, Professor, Department of Mechanical Engineering of Agricultural Machinery, University of Tehran, Karaj, Iran. Corresponding author: Akinbode Adedeji, 128 C.E. Barnhart Building, University of Kentucky, Lexington, KY 40546; phone: 859-2184355; e-mail: akinbode.adedeji@uky.edu. to ensure that all fruits meet a minimum level of acceptance.

During the last few decades, considerable studies have been carried out on the development of non-destructive evaluation methods for fruit properties based on different technologies, e.g., sonic (Morrison and Abeyratne, 2014), electrical (El Khaled et al., 2015), machine vision (Parmar et al., 2011), Vis/NIR spectroscopy (McGlone et al., 2002; Rungpichayapichet et al., 2016), hyperspectral imaging (HSI) (Lu, 2003; Mendoza et al., 2011), computed tomography (CT) (Ma et al., 2016), nuclear magnetic resonance (NMR) (Hernández-Sánchez et al., 2007), and electronic nose (Xiaobo et al., 2010). As table 1 shows, none of these approaches seems to provide all the information necessary to predict fruit quality. Additionally, non-destructive detection methods have their advantages and drawbacks. For example, optical methods provide better detection of external properties than internal properties, and sonic methods are still experimental and have not been applied commercially. Consequently, different measuring principles should be applied in parallel to improve the available information on fruit quality.

Hyperspectral imaging (HSI) is a relatively new technology that produces a spatial map of the spectral variation of the tested sample, and thus it is a useful tool in evaluation applications in agricultural and food industries (Ekramirad et al., 2016). HSI integrates spectroscopic and imaging techniques to enable direct identification of different components and changes and their spatial distribution in the tested sample using a three-dimensional dataset called a hypercube. A hypercube contains a large amount of information that can be analyzed to describe the object in a more reliable manner than conventional machine vision or spectroscopy methods. HSI technology can provide more detection information, in- 
Table 1. Non-destructive methods for prediction of fruit quality attributes.

\begin{tabular}{|c|c|c|c|}
\hline Basis & Method Used & Properties & References \\
\hline \multirow[t]{3}{*}{ Optical } & $\begin{array}{l}\text { Image processing and } \\
\text { machine vision }\end{array}$ & Size, shape, external defects & Blasco et al. (2003), Hatcher (2008) \\
\hline & Spectroscopy & $\begin{array}{l}\text { Sugar, acidity, total soluble solids, color, } \\
\text { internal and external defects, firmness }\end{array}$ & $\begin{array}{c}\text { Nicolaï et al. (2007), } \\
\text { Rungpichayapichet et al. (2016) }\end{array}$ \\
\hline & Hyperspectral imaging & $\begin{array}{l}\text { Sugar, acidity, total soluble solids, color, size, } \\
\text { shape, internal and external defects, firmness }\end{array}$ & $\begin{array}{c}\text { Huang et al. (2014), Lu and Peng (2006), } \\
\text { Nanyam et al. (2012), Pu et al. (2015) }\end{array}$ \\
\hline X-ray & $\begin{array}{l}\text { X-ray imaging and } \\
\text { computed tomography }\end{array}$ & Internal cavity, maturity & Schoeman et al. (2016) \\
\hline \multirow[t]{2}{*}{ Acoustic } & Vibrational & Firmness, viscoelasticity, maturity & Ikeda et al. (2015), Liu and Hui (2015) \\
\hline & Sound and ultrasound & $\begin{array}{c}\text { Firmness, viscoelasticity, internal cavity, } \\
\text { density, sugar }\end{array}$ & Mizrach et al. (2000) \\
\hline Electromagnetic & $\begin{array}{c}\text { Magnetic resonance imaging and } \\
\text { nuclear magnetic resonance }\end{array}$ & $\begin{array}{l}\text { Sugar, moisture content, internal cavity, } \\
\text { internal defects }\end{array}$ & $\begin{array}{c}\text { Mazhar et al. (2015), } \\
\text { Winisdorffer et al. (2015) }\end{array}$ \\
\hline Chemical & E-nose and E-tongue & Acidity, sugar & Baietto and Wilson (2015) \\
\hline
\end{tabular}

cluding internal characteristics, morphology, and chemical composition, than a single machine vision technology or spectroscopic analysis technology. HSI technology has been used for predicting internal qualities such as TSS, firmness, and $\mathrm{pH}$ of peaches (Lu and Peng, 2006), blueberries (LeivaValenzuela et al., 2013), strawberries (ElMasry et al., 2007), and bananas (Rajkumar et al., 2012). For apples, Peng and $\mathrm{Lu}$ (2005) investigated the firmness and TSS of 'Golden Delicious' apples, Mendoza et al. (2011) predicted the firmness and TSS of three varieties of apples ('Jonagold', 'Red Delicious', and 'Golden Delicious'), and Dong and Guo (2015) used this method to study the TSS, firmness, and $\mathrm{pH}$ of 'Fuji' apples. The results of these studies showed that HSI is feasible for non-destructively predicting internal quality attributes of fruits. However, the results also indicated that this method could not predict all attributes exactly, and some properties were evaluated coarsely or were not predicted.

Acoustic emission (AE) techniques, especially within the ultrasonic frequency range, have the advantages of quick measurement and interpretation, high accuracy, low cost, freedom from radiation hazards, ease of on-line measurement, and characterization of the entire sample rather than being site-specific. Therefore, AE techniques have gained increasing popularity in the assessment of biological materials and foodstuffs. The characteristics of the sound waves that pass through the product can be used to indicate the quality attributes of fruit during postharvest processing (Butz et al., 2005). Mizrach et al. (2000) reported using an ultrasonic measurement system for assessment of some transmission parameters. Those parameters may have quantitative relationships with ripening, maturity, firmness, and other internal qualities of fruit and vegetables. Thus, in the present study, a novel approach was applied to record the ultrasound emission signals of intact apples using a contact piezoelectric sensor in order to predict the fruit internal qualities based on time domain and frequency domain parameters of the collected signals.

Applying novel technologies as well as combining different methods in the field of post-harvest fruit quality assessment could increase the prediction accuracy of both internal and external quality attributes. Moreover, it is necessary to evaluate these methods in order to propose a new sensor fusion approach for more accurate and robust assessment of fruit quality. Therefore, the objectives of this study were to propose a novel $\mathrm{AE}$ technique for fruit quality prediction and to compare the performance of AE and HSI techniques in predicting quality characteristics of apples.

\section{Materials ANd Methods \\ SAMPLES AND REFERENCE ANALYSES}

Apples of 'GoldRush' variety were harvested from a commercial orchard in Georgetown, Kentucky, during the 2015 harvest season. The apples were transported to our laboratory at the University of Kentucky, where they were washed in clean potable water with detergent to remove insecticide residues, and then air-dried. The apples were then divided equally into four groups and placed in storage conditions of $27^{\circ} \mathrm{C}, 17^{\circ} \mathrm{C}, 10^{\circ} \mathrm{C}$, and $4^{\circ} \mathrm{C}$ at a relative humidity that ranged from $75 \%$ to $90 \%$. Measurements were taken initially and at one-week intervals during the eight-week storage period, and thus the samples varied in their quality attributes. Three replicates were taken from each storage condition. Intact apples were marked and scanned by an HSI system, and $\mathrm{AE}$ signals were recorded before carrying out destructive tests, which included firmness, TSS, and surface color ( $\mathrm{L}^{*}, \mathrm{a}^{*}$, and $\mathrm{b}^{*}$ space indices) measurements. Standard destructive methods were applied to measure quality attributes for reference values. Fruit firmness was measured using a texture analyzer (CT3, Ametek Brookfield) to perform a puncture test, using a $11 \mathrm{~mm}$ diameter steel cylindrical probe at a compression depth of $8 \mathrm{~mm}$. Maximum force $(\mathrm{N})$ recorded by a Magness-Taylor (MT) tester is considered to be a measure of fruit firmness. TSS was obtained by squeezing flesh samples to extract the juice in order to measure the refractive index on a compensated digital refractometer (Leica Auto Abbe). The measurement of apple peel color was carried out using a Minolta Chromameter (CR300 Series). The color was expressed in terms of $\mathrm{L}^{*}, \mathrm{a}^{*}$, and $\mathrm{b}^{*}$ color indices, where $\mathrm{L}$ denotes lightness on a scale of 100 to 0 , a- denotes greenness while $\mathrm{a}+$ denotes redness, and $\mathrm{b}-$ denotes blueness while $\mathrm{b}+$ denotes yellowness. All reference measurements were repeated three times on each sample.

\section{HYPERSPECTRAL IMAGING SYSTEM}

An HSI system (Middleton Spectral Vision) was used for acquiring reflectance images from the apple samples in the spectral range of 400 to $1000 \mathrm{~nm}$. The line scan (pushbroom) system is made up of four main parts (fig. 1): a sample plate (model MRC-999-031, Middleton Spectral Vision), $150 \mathrm{~W}$ 


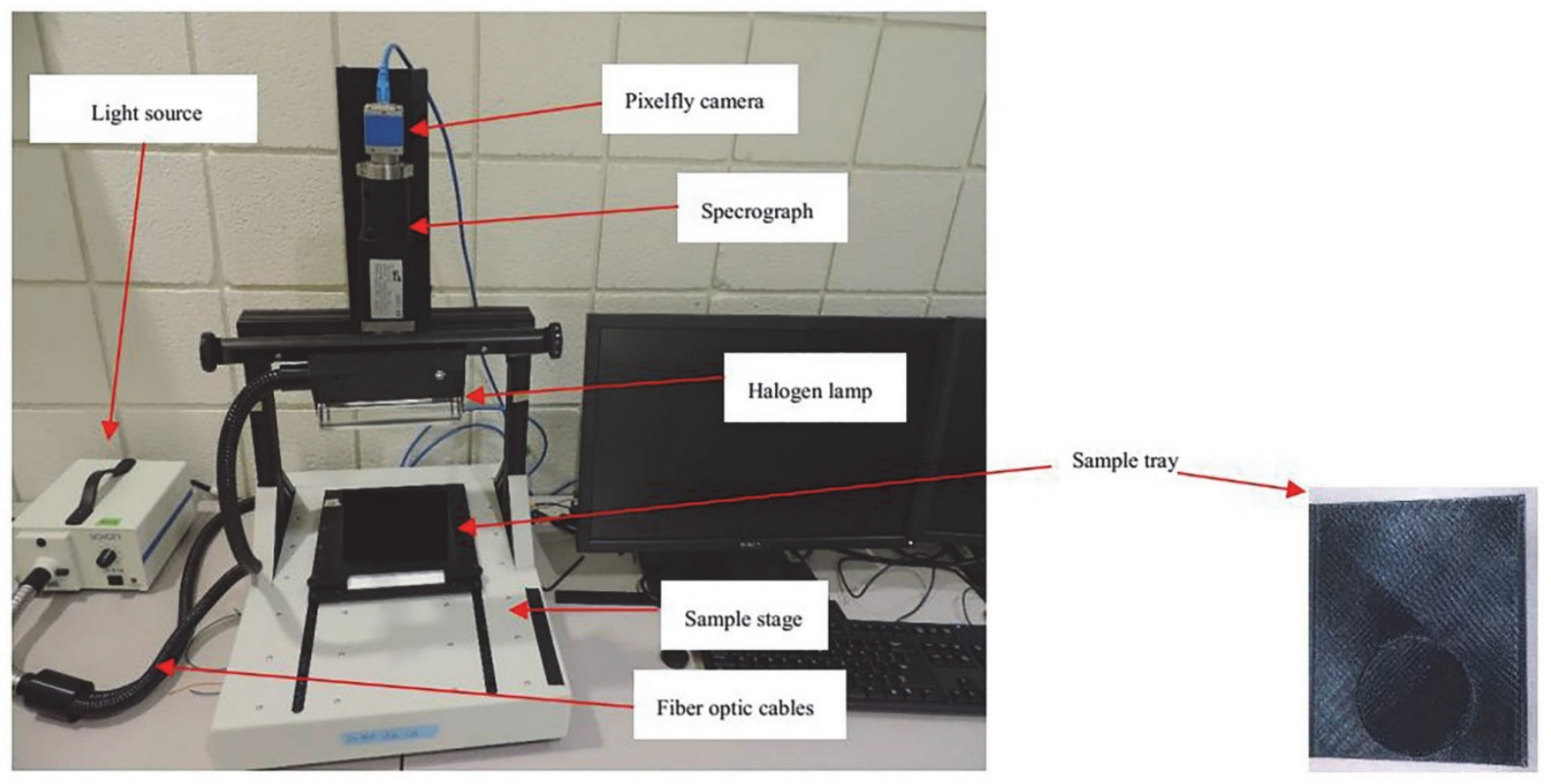

Figure 1. Hyperspectral imaging system at the University of Kentucky Food Engineering Laboratory.

halogen lamp (model A20800, Schott) positioned above the sample at a $45^{\circ}$ angle, a Pixelfly CCD digital camera with 12 bit $(69.5 \mathrm{~dB})$ dynamic range coupled with a zoom lens, and a spectrograph (model V10E, Specim) attached to the front of the camera lens. The adjusted configurations were $2 \times 2$ binning, $45 \mathrm{~ms}$ exposure time, and scanning speed of 3322 counts $\mathrm{s}^{-1}$. Spectral and spatial resolutions were $2.8 \mathrm{~nm}$ and $0.13 \mathrm{~mm} \mathrm{pixel}^{-1}$, respectively. The output image (*.raw) had a size of $696 \times 619$ pixels with 512 spectral bands forming a hypercube.

\section{IMAge Processing AND HYPERSPECTRAL \\ DAta Analysis}

Each apple was placed on a black plastic tray and scanned four times at the stem, calyx end, and twice from different sides around the equator. The data from averaging all four orientations were used in the modeling. To segment the region of interest (ROI) from the images, the image with a wavelength of $710 \mathrm{~nm}$ was considered as a masking image, which is a binary image obtained by the histogram thresholding technique. This masking image was then applied on each image of the hypercube (i.e., all 512 wavelengths) to obtain the ROI, which contains only the sample, with other pixels representing the background equal to zero. The mean reflectance spectrum (MRS) was computed by averaging over all the pixels for each segmented ROI. Each image was then calibrated using the MRS of a $50 \%$ reference plate (SRT-40-050, Labsphere) and the MRS of the dark or background. The relative reflectance (RR) was calculated using the following equation:

$$
\mathrm{RR}=\frac{I_{s(i)}-I_{d(i)}}{I_{r(i)}-I_{d(i)}}
$$

where $I_{s}, I_{r}$, and $I_{d}$ are the intensity values for the sample, reference, and dark, respectively. Subscript $i$ refers to the pixel index $(i=1,2,3, \ldots, n$, where $n$ is the size of the MRS vector). Figure 2 shows the sequence of image processing steps followed to obtain the MRS.

The spectral data (fig. 3) were analyzed using PLS regression with preprocessing. Several spectral preprocessing methods, including standard normal variate (SNV), mean centering, multiplicative signal correction (MSC), smoothing using first and second derivatives, and $\min / \max$ normalization, were applied in addition to the non-preprocessed data, and the best preprocessing approach was selected based on the standard error (Rady et al., 2015). The purpose of spectral preprocessing is to eliminate the effects of noise, distortion, and observational environment and to improve the precision and stability of models.

The multicollinearity problem usually occurs in multivariate analysis of hyperspectral images. Some congruous wavelengths are related to similar constituents and thus contain much of the same information. Therefore, it is essential to find the few characteristic wavelengths that would be most effective for quality evaluation of the product and to eliminate wavelengths with no discrimination power. The interval partial least squares (IPLS), which is a known variable selection method for spectroscopic data and for optimizing the performance of PLSR models, was applied in this research.

All image processing and feature extraction of the acquired hyperspectral images was carried out using MATLAB (R2014b, The MathWorks, Inc.), and PLS calibration models were developed in MATLAB with the routines of the PLS-Toolbox (Eigenvector Research, Inc.) to predict fruit quality parameters.

\section{Acoustic Emission Test and Data Analysis}

An experimental AE monitoring apparatus was customdesigned and developed by TriboFlow Separations Co. (Lexington, Ky.) to acquire high-quality ultrasound emis- 


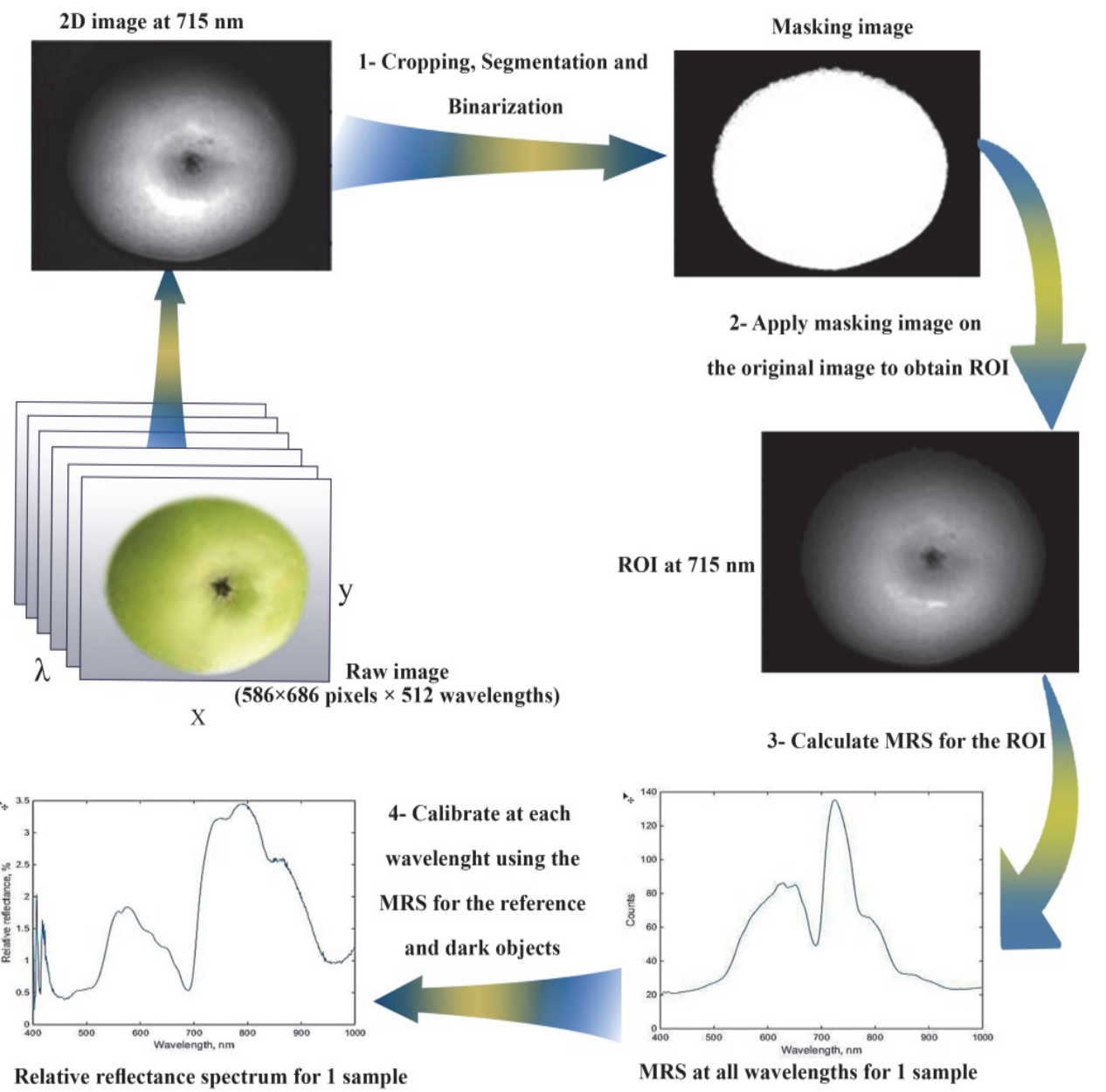

Figure 2. Steps followed to obtain MRS for raw images of apple samples scanned using visible/near-infrared imaging system.

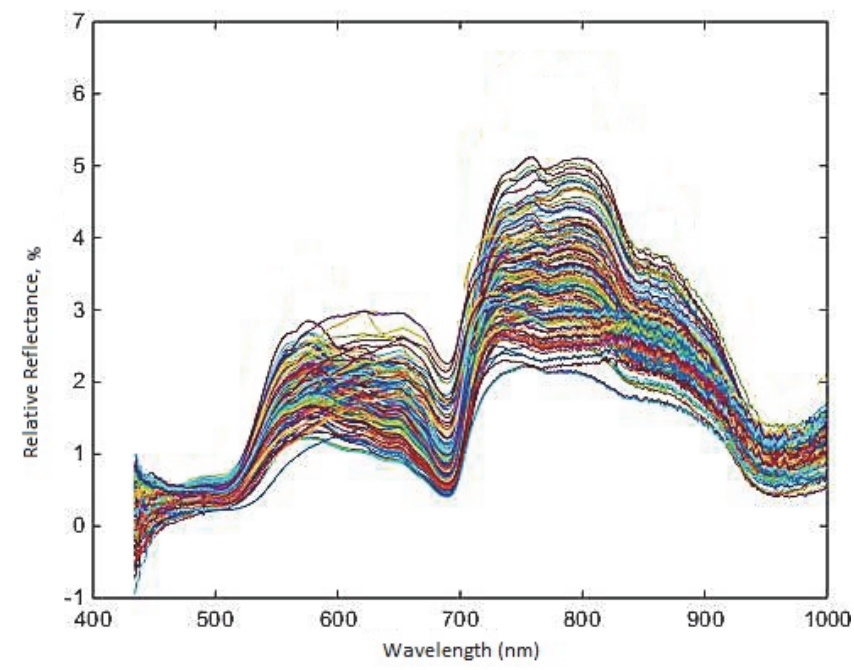

Figure 3. Relative reflectance of spectral data for regression analysis.

sion data from apple samples (fig. 4). The apparatus consists of a rectangular stainless steel compartment enclosing a chamber that was sound and vibration isolated, an acoustic piezoelectric ceramic sensor (R6 a model SNAD54, Physical Acoustics Corp.) with an operating frequency range of 35 to $100 \mathrm{kHz}$, a $40 \mathrm{~dB}$ preamplifier (1220A, Physical Acoustics Corp.), and a designated channel to preprocess the signals.
Data were collected and analyzed using AEwin software (Physical Acoustics Corp.), which performed fast Fourier transform on the data and provided the various features and parameters of the sound obtained from the sample automatically.

To acquire acoustic data, the setup shown in figure 4 was used. First, a background signal was collected to set the threshold input parameter in the data acquisition software. When acoustic wave intensities above the threshold were detected (called a "hit"), the software enabled storage, and signal data were recorded. To obtain acoustic signals, each apple was placed inside the chamber in contact with the piezoelectric sensor, and a recording time of $60 \mathrm{~s}$ was used for each sample. Nine features were obtained (seven time domains and two frequency domains): rise time, number of counts, energy, amplitude, signal strength, absolute energy, frequency centroid, and peak frequency. These features were used as predictors to model the quality parameters.

\section{MODELING Methods}

Two linear models, i.e., multivariate linear regression (MLR) and partial least squares (PLS), and one nonlinear model, i.e., least squares support vector machine (LS-SVM), were applied to establish prediction models for firmness, TSS, and the three color parameters. MLR predicts the de- 


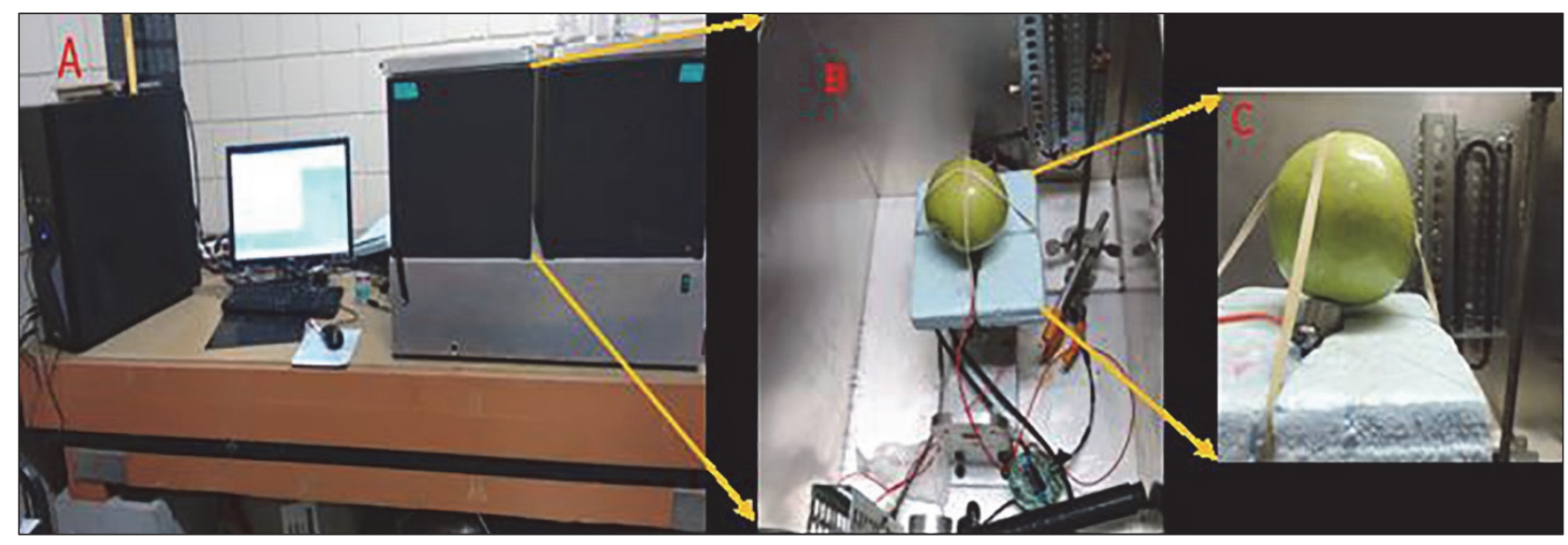

Figure 4. Acoustic setup.

pendent variables by a linear combination of predictor values at each data point, and the error between predicted and measured values is minimized in a least squares sense. MLR is a simple method used for explanatory or predictive purposes; however, in prediction analysis, multicollinearity between the variables reduces the performance of the model. Thus, LS-SVM was also applied as a non-linear model to deal with non-linearity of the data. LS-SVM, proposed by Suykens et al. (2002), is a modified algorithm of the standard support vector machine (SVM), which is an emerging machine learning algorithm that improves the generalization ability of the learning machine based on the principle of structural risk minimization (Yu et al., 2011). LS-SVM is widely applied in pattern recognition and function regression due to the advantages of limited overfitting, high predictive reliability, and strong generalization ability, which is especially feasible for circumstances of small sample space modeling. In this study, we applied LS-SVM with radial basis function (RBF) kernel in prediction of quality parameters from the acoustic signals. The simplex technique and leaveone-out cross-validation were applied to find the two turning parameters, i.e., regularization parameter $(\gamma)$ and kernel function parameters $\left(\sigma^{2}\right)$, of LS-SVM. The LS-SVMlab Toolbox (v. 1.8, Katholieke Universiteit Leuven) was employed for LS-SVM regression. The computations and data analysis were performed in MATLAB (R2014b, The MathWorks, Inc.).

Generally, PLS is implemented in spectral data analysis to transfer the large sets of highly correlated and often collinear experimental data into smaller factors. PLS is a widely used algorithm that combines factor analysis techniques with regression. In PLS, the original independent information (spectral data) is projected onto a few underlying variables called latent variables (LVs) to reduce the dimensionality and compress the original spectral data (Dong and Guo, 2015; Li et al., 2013). Synthesizing the sense of principal component analysis (PCA) and MLR, PLS regression is especially feasible in circumstances where multicollinearity exists between the variables, and the number of LVs is usually smaller than in PCR regression. The optimum number of latent variables was selected based on minimizing the standard error of cross-validation by selecting the first minimum calculated with the leave-one-out method.
The predictive ability of a model is evaluated by model parameters such as the correlation coefficient (r) and root mean square error of prediction (RMSEP) between the predicted value and the measured value in the validation set (Wang et al., 2015). Another commonly used evaluation parameter is the residual predictive deviation (RPD), which is the ratio of the standard deviation of the dependent variable to the RMSEP. According to Nicola et al. (2007) and Pissard et al. (2013), when the RPD value of a prediction model is between 2 and 2.5, coarse prediction is possible, while an RPD value above 2.5 indicates good to excellent prediction. In this study, the correlation coefficient (r), RMSEP, and RPD were used to evaluate the models.

\section{RESULTS AND DISCUSSION \\ QUALITY CHARACTERISTICS OF SAMPLES}

The statistics of firmness, TSS, and color parameters of the apples, used as calibration and prediction sets, are shown in table 2. For each parameter, the measured data range in the prediction set was within the limits of the data in the calibration set. In addition, the standard deviation of each parameter was $23 \%$ to $40 \%$ of the data range of that parameter in both sets. This means that the data contained enough variation for a meaningful calibration (Dong and Guo, 2015; Savenije et al., 2006). Moreover, each quality parameter in the two sets covered a similar range. All these factors suggest a meaningful sample division, leading to effective models.

As shown in table 2, broad ranges of values were measured for firmness ( 28 to $59.78 \mathrm{~N}$ ) and for the three color parameters. This can be attributed to the fact that sampling was carried out at different times during an eight-week period with four different storage conditions. It is well known that firmness declines during storage as a result of changes in water content and pectin transformation, leading to a loss of cell wall integrity, cell-to-cell adhesion, increase in intercellular spaces, and a change in tissue structure (Cybulska et al., 2012; Zude et al., 2006). The increase in $b^{*}$ values, a variation from blueness to yellowness (from 29.87 to 51.43 for apples stored at $4^{\circ} \mathrm{C}$ ), could be associated with a yellowing tendency, which usually indicates ripening. In fact, the skin color of 'GoldRush' apple is greenish-yellow with an occasional bronze to red blush at harvest, and the skin turns deep 
Table 2. Descriptive statistics of the calibration and prediction data sets.

\begin{tabular}{|c|c|c|c|c|c|c|c|}
\hline \multirow[b]{2}{*}{$\begin{array}{c}\text { Quality } \\
\text { Parameter }\end{array}$} & \multirow[b]{2}{*}{$\begin{array}{c}\text { Sample } \\
\text { Set }\end{array}$} & \multicolumn{3}{|c|}{ Acoustic Emission Test } & \multicolumn{3}{|c|}{ Hyperspectral Imaging } \\
\hline & & $\begin{array}{c}\text { No. of } \\
\text { Samples }\end{array}$ & $\begin{array}{c}\text { Range of } \\
\text { Measured Data }\end{array}$ & Mean \pm SD & $\begin{array}{c}\text { No. of } \\
\text { Samples }\end{array}$ & $\begin{array}{c}\text { Range of } \\
\text { Measured Data }\end{array}$ & Mean \pm SD \\
\hline \multirow{2}{*}{ Firmness $(\mathrm{N})$} & Calibration & 100 & 28.00 to 56.87 & $41.71 \pm 9.68$ & 113 & 28.00 to 59.78 & $34.34 \pm 12.53$ \\
\hline & Prediction & 30 & 31.50 to 55.75 & $42.74 \pm 9.36$ & 37 & 17.75 to 52.90 & $34.87 \pm 10.75$ \\
\hline \multirow{2}{*}{ TSS ( ${ }^{\circ}$ Brix) } & Calibration & 100 & 11.20 to 16.1 & $13.70 \pm 1.13$ & 132 & 11.11 to 17.12 & $14.13 \pm 4.03$ \\
\hline & Prediction & 30 & 11.20 to 14.85 & $13.49 \pm 1.07$ & 43 & 11.10 to 16.25 & $13.81 \pm 1.12$ \\
\hline \multirow{2}{*}{$\mathrm{L}^{*}$} & Calibration & 100 & 48.99 to 72.23 & $60.61 \pm 5.73$ & 108 & 46.76 to 74.34 & $62.21 \pm 5.87$ \\
\hline & Prediction & 30 & 51.98 to 68.91 & $61.11 \pm 5.49$ & 36 & 52.74 to 73.12 & $63.00 \pm 5.77$ \\
\hline \multirow{2}{*}{$a^{*}$} & Calibration & 100 & -18.70 to -8.37 & $-14.38 \pm 2.69$ & 108 & -27.17 to -1.33 & $-11.18 \pm 5.37$ \\
\hline & Prediction & 30 & -18.41 to -10.66 & $-14.65 \pm 2.29$ & 36 & -18.42 to -0.95 & $-11.19 \pm 4.55$ \\
\hline \multirow{2}{*}{$\mathrm{b}^{*}$} & Calibration & 100 & 24.88 to 55.43 & $35.21 \pm 10.15$ & 108 & 23.36 to 61.74 & $39.26 \pm 12.44$ \\
\hline & Prediction & 30 & 26.58 to 50.70 & $34.63 \pm 10.00$ & 36 & 27.08 to 59.90 & $39.00 \pm 12.46$ \\
\hline
\end{tabular}

yellow during storage (Crosby et al., 1994). The values of firmness, TSS, and color parameters in this work were within the ranges for apples found in the literature (Jiménez et al., 2011; Mendoza et al., 2011).

\section{Prediction of Quality ATtributes BY ACOUSTIC EMISSION}

The calibration and prediction performances of the LSSVM and MLR models for firmness, TSS, and color parameters of apples are listed in table 3. For the MLR model, the RPD values of the color indices were not higher than 1.20 , indicating that the established MLR model was incapable of predicting the color of apples using the AE technique. However, LS-SVM has better comprehensive ability than MLR in predicting all the quality parameters, indicating the nonlinear nature of the acoustic data. A high correlation between firmness and the acoustic data was found, and the LS-SVM model for firmness prediction achieved a relatively good performance for both the calibration set and the prediction set, with a correlation coefficient $\left(r_{c}\right)$ and root mean square error of calibration (RMSEC) of 0.97 and $2.33(\mathrm{~N})$, respectively, correlation coefficient of prediction $\left(\mathrm{r}_{\mathrm{p}}\right)$ and RMSEP of 0.88 and $4.26(\mathrm{~N})$, respectively, and RPD of 2.25. The parameters of the LS-SVM model optimized by leave-one-out cross-validation were $\sigma^{2}=0.24$ and $\gamma=9.32$. Acoustic signals are transmitted mainly by the fruit cell walls due to their elastic properties and ability to generate elastic waves; therefore, it was expected that the fruit firmness and structural properties would correlate highly with acoustic parameters.

For color parameter prediction, LS-SVM has good results for $b^{*}$, with $r_{c}$ and RMSEC of 0.98 and 0.08 , respectively, $r_{p}$ and RMSEP of 0.81 and 5.17, respectively, and RPD of 1.80 . The optimized LS-SVM model using leave-one-out crossvalidation method had kernel parameters of $\sigma^{2}=0.82$ and $\gamma=$
606.5. However, the model had poor performance in predicting the $\mathrm{a}^{*}$ and $\mathrm{L}^{*}$ parameters, as indicated by the high RMSEP and low RPD values.

Table 3 shows that the AE technique was moderately successful for TSS prediction, with $r_{c}$ and RMSEC of 0.81 and 0.75 ( ${ }^{\circ}$ Brix), respectively, $r_{p}$ and RMSEP of 0.76 and 0.60 ( ${ }^{\circ}$ Brix), respectively, and RPD of 1.77 by MLR, and $r_{c}$ and RMSEC of 0.75 and 0.62 ( ${ }^{\circ}$ Brix), respectively, $r_{p}$ and RMSEP of 0.74 and 0.64 ( ${ }^{\circ}$ Brix), respectively, and RPD of 1.68 by LS-SVM.

Figure 5 shows the predicted values for firmness, TSS, and color parameters of the apples obtained by the MLR and LS-SVM models versus the measured values. The overall prediction results for LS-SVM were better than those for MLR. However, the two modeling methods yielded similar predictions for TSS, with $r_{p}$ values between 0.76 and 0.76 .

\section{Predicting APPle Quality ATtributes USING HYPERSPECTRAL IMAGING}

Table 4 summarizes the quality attribute predictions for the apples by the PLS model with the most promising preprocessing methods and using all spectral wavelengths. Similarly, table 5 presents the predictions using the PLS model with selected wavelengths using IPLS. As shown in tables 4 and 5, good firmness and color value predictions were obtained, whereas relatively poor results were obtained for TSS $\left(r_{p}=0.34, \operatorname{RMSEP}=1.86\left({ }^{\circ}\right.\right.$ Brix $)$, and RPD $=1.04$ using all wavelengths, and $\mathrm{r}_{\mathrm{p}}=0.41$, RMSEP $=1.78$ ( ${ }^{\circ}$ Brix), and RPD $=1.09$ using selected wavelengths). This is in agreement with other studies, proving that HSI in reflectance and scattering modes shows better performance for firmness and color prediction than for TSS prediction, and the presence of skin defects and bruises on intact samples negatively influences the prediction of TSS (Lu and Peng, 2007; Mendoza

Table 3. Results of quality attribute prediction of apples using AE by two models.

\begin{tabular}{|c|c|c|c|c|c|c|}
\hline \multirow{2}{*}{$\begin{array}{c}\text { Quality } \\
\text { Parameter }\end{array}$} & \multirow{2}{*}{$\begin{array}{c}\text { Prediction } \\
\text { Model }\end{array}$} & \multicolumn{2}{|c|}{ Calibration Set } & \multicolumn{3}{|c|}{ Prediction Set } \\
\hline & & $r_{c}$ & RMSEC & $r_{p}$ & RMSEP & RPD \\
\hline \multirow{2}{*}{ Firmness (N) } & MLR & 0.83 & 5.32 & 0.74 & 5.76 & 1.66 \\
\hline & LS-SVM & 0.97 & 2.19 & 0.88 & 4.26 & 2.25 \\
\hline \multirow{2}{*}{ TSS ( ${ }^{\circ}$ Brix) } & MLR & 0.81 & 0.75 & 0.76 & 0.60 & 1.77 \\
\hline & LS-SVM & 0.75 & 0.62 & 0.74 & 0.64 & 1.68 \\
\hline \multirow{2}{*}{$\mathrm{L}^{*}$} & MLR & 0.70 & 4.86 & 0.10 & 5.60 & 0.97 \\
\hline & LS-SVM & 0.86 & 2.76 & 0.34 & 4.69 & 1.16 \\
\hline \multirow{2}{*}{$a^{*}$} & MLR & 0.43 & 2.88 & 0.04 & 2.48 & 0.92 \\
\hline & LS-SVM & 0.56 & 2.17 & 0.37 & 1.80 & 1.27 \\
\hline \multirow{2}{*}{$b^{*}$} & MLR & 0.80 & 7.24 & 0.20 & 9.48 & 1.10 \\
\hline & LS-SVM & 0.98 & 0.08 & 0.81 & 5.17 & 1.80 \\
\hline
\end{tabular}




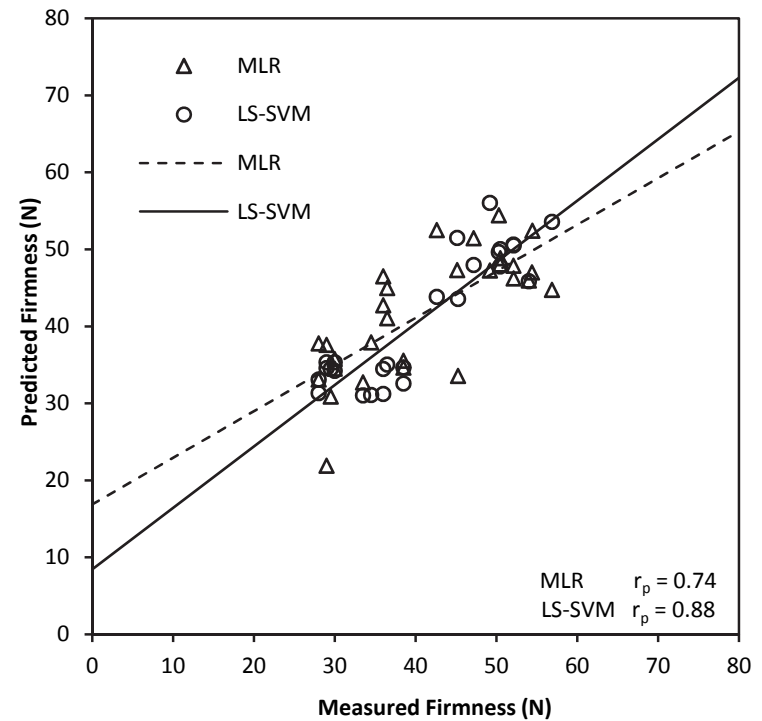

(a)

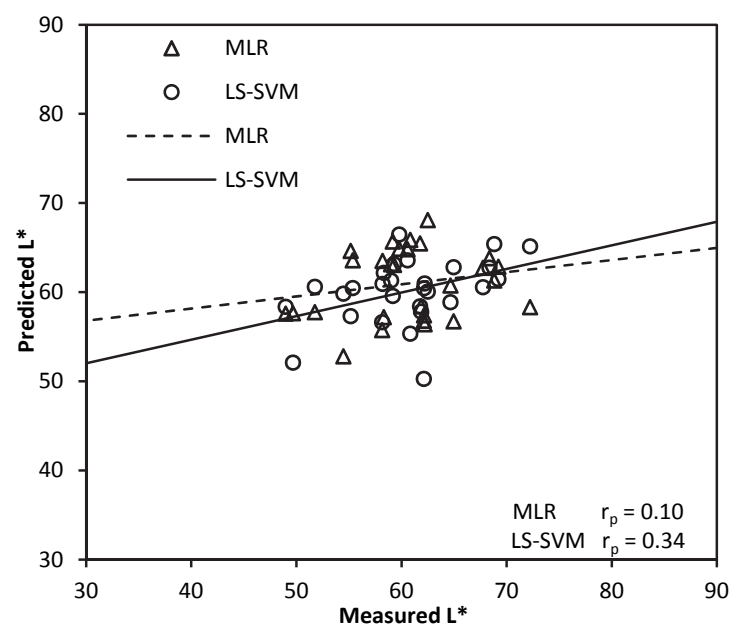

(c)

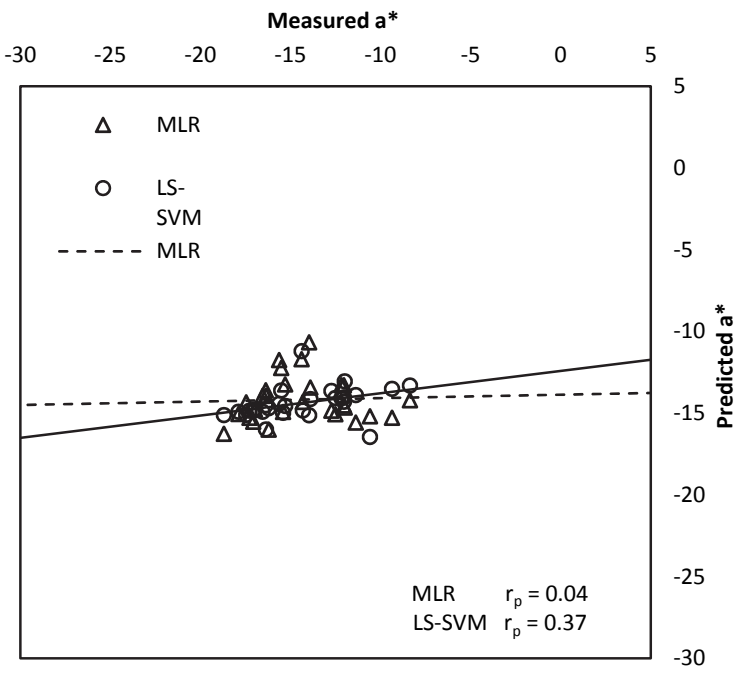

(b)

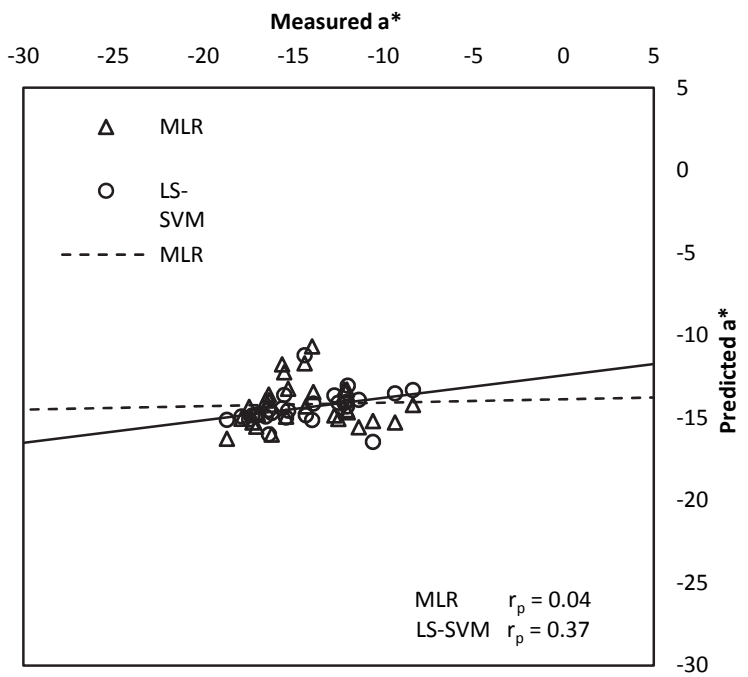

(d)

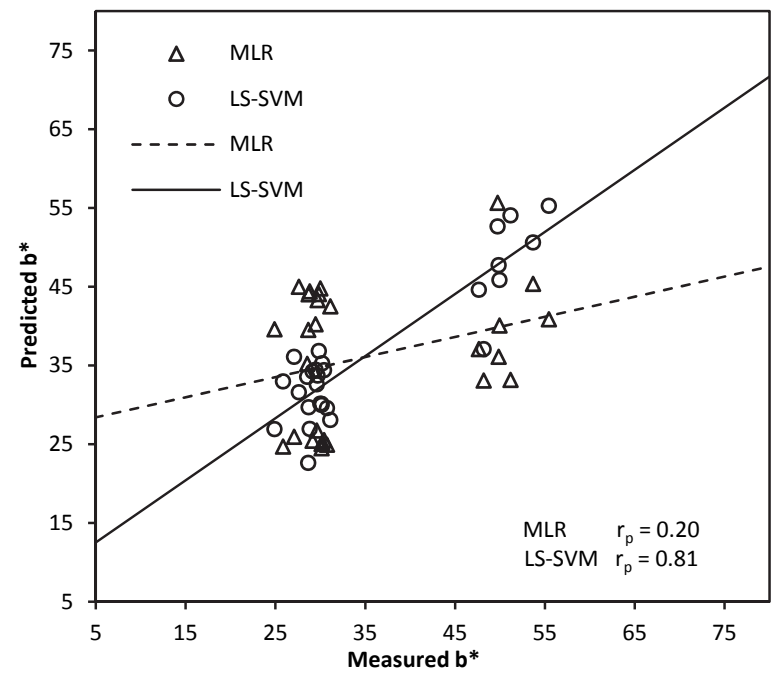

(e)

Figure 5. Measured versus predicted (a) firmness, (b) TSS, (c) $L^{*}$, (d) $a^{*}$, and (e) $b^{*}$ for prediction sets using AE by MLR and LS-SVM regression. 
Table 4. Results of PLS using all wavelengths (483 wavelengths out of 512, others are noise).

\begin{tabular}{|c|c|c|c|c|c|c|c|}
\hline \multirow{2}{*}{$\begin{array}{c}\text { Quality } \\
\text { Parameter }\end{array}$} & \multirow{2}{*}{$\begin{array}{c}\text { Spectra } \\
\text { Preprocessing }\end{array}$} & \multicolumn{2}{|c|}{ Calibration Set } & \multirow{2}{*}{$\begin{array}{c}\text { Number of } \\
\text { Latent Variables }\end{array}$} & \multicolumn{3}{|c|}{ Prediction Set } \\
\hline & & $\mathrm{r}_{\mathrm{c}}$ & RMSEC & & $r_{p}$ & RMSEP & RPD \\
\hline Firmness (N) & SNV correction & 0.95 & 5.64 & 12 & 0.89 & 5.94 & 1.81 \\
\hline TSS ( ${ }^{\circ}$ Brix $)$ & No preprocessing & 0.63 & 1.11 & 5 & 0.34 & 1.86 & 1.04 \\
\hline $\mathrm{L}^{*}$ & Normalization & 0.85 & 3.06 & 9 & 0.82 & 3.39 & 1.70 \\
\hline$a^{*}$ & Median center & 0.91 & 3.44 & 2 & 0.90 & 2.06 & 2.21 \\
\hline$b^{*}$ & Smoothing, 2nd derivative & 0.98 & 2.50 & 3 & 0.96 & 3.85 & 3.23 \\
\hline
\end{tabular}

Table 5. Results of PLS using selected wavelengths using IPLS.

\begin{tabular}{|c|c|c|c|c|c|c|c|}
\hline \multirow{2}{*}{$\begin{array}{c}\text { Quality } \\
\text { Parameter }\end{array}$} & \multirow{2}{*}{$\begin{array}{c}\text { Spectra } \\
\text { Preprocessing }\end{array}$} & \multicolumn{2}{|c|}{ Calibration Set } & \multirow{2}{*}{$\begin{array}{c}\text { Number of } \\
\text { Latent Variables }\end{array}$} & \multicolumn{3}{|c|}{ Prediction Set } \\
\hline & & $\mathrm{r}_{\mathrm{c}}$ & RMSEC & & $r_{p}$ & RMSEP & RPD \\
\hline Firmness (N) & Median centering & 0.95 & 5.66 & 21 & 0.92 & 4.32 & 2.49 \\
\hline TSS ( ${ }^{\circ}$ Brix $)$ & Normalization & 0.67 & 1.06 & 15 & 0.41 & 1.78 & 1.09 \\
\hline $\mathrm{L}^{*}$ & Smoothing, 2nd derivative & 0.83 & 3.90 & 11 & 0.83 & 3.41 & 1.69 \\
\hline$a^{*}$ & No preprocessing & 0.87 & 2.92 & 8 & 0.87 & 2.28 & 1.99 \\
\hline$b^{*}$ & MSC & 0.94 & 5.17 & 16 & 0.94 & 4.29 & 2.91 \\
\hline
\end{tabular}

et al., 2011; Wang et al., 2015). Moreover, changes in other factors, such as relative water content, might affect TSS prediction due to absorption at the same wavelengths (Zude et al., 2006). However, spectroscopy and HSI combined with other techniques might perform well in the prediction of TSS. For instance, Xiaobo et al. (2010) combined near-infrared spectroscopy, a machine vision system, and an electronic nose to classify 'Fuji' apples based on sugar content, reducing the classification error by $17 \%$.

HSI and spectroscopy in the near-infrared region have been widely used for firmness prediction of fruits based on the differences in scattering and absorption caused by changes in cell wall composition and cell collapse as a result of decreased moisture content (Louw and Theron, 2010). Among many fruits, apples have gained great attention in firmness prediction using HSI (Pu et al., 2015). As shown in tables 4 and 5, the PLS model for firmness prediction of apples in this study achieved high performance for both the training set and the prediction set $\left(r_{c}=0.95, r_{p}=0.89\right.$, and RPD $=1.81$ using all wavelengths, and $r_{c}=0.95, r_{p}=0.92$, and RPD $=2.49$ using selected wavelengths), and these results are comparable to those reported in other studies (Mendoza et al., 2011; Wang et al., 2012; Zhu et al., 2013).

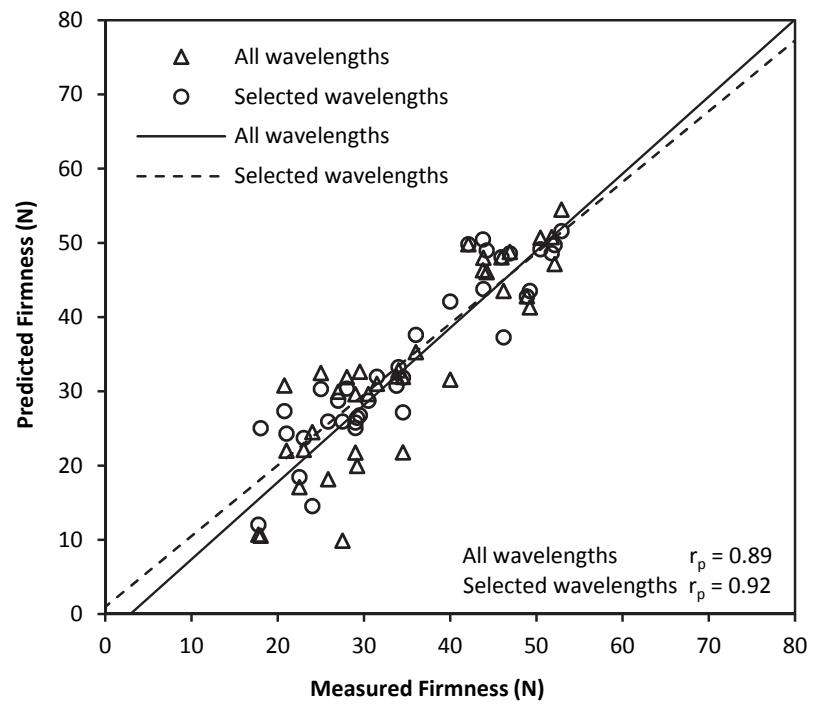

(a)
Measured values of the quality attributes from the reference destructive tests and the predicted values from the PLS models using all wavelengths and selected wavelengths are shown in figure 6 . Good correlation was observed between measured and predicted firmness and the $\mathrm{L}^{*}$, $\mathrm{a}^{*}$, and $\mathrm{b}^{*}$ color indices for the prediction set of the apples. Given that both the Minolta Chromameter and the HSI system measure light reflectance in the visible region, strong correlation between these measurements was expected (figs. 6c to 6e).

\section{CONCLUSION}

This research evaluated HSI and a novel acoustic emission (AE) technique for the prediction of some quality attributes of 'GoldRush' apples by developing prediction models. The AE technique showed high correlations with firmness $\left(r_{c}\right.$ and RMSEC of 0.97 and $2.33(\mathrm{~N})$, respectively, and $r_{p}$ and RMSEP of 0.88 , and $4.26(\mathrm{~N})$, respectively) and $\mathrm{b}^{*}$ color in$\operatorname{dex}\left(r_{c}\right.$ and RMSEC of 0.98 and 0.08 , respectively, and $r_{p}$ and RMSEP of 0.80 and 5.17, respectively), which suggests a promising application for simple and effective monitoring of apple quality. On the other hand, HSI had good prediction results for firmness $\left(r_{c}\right.$ and RMSEC of 0.95 and $5.66(\mathrm{~N})$,

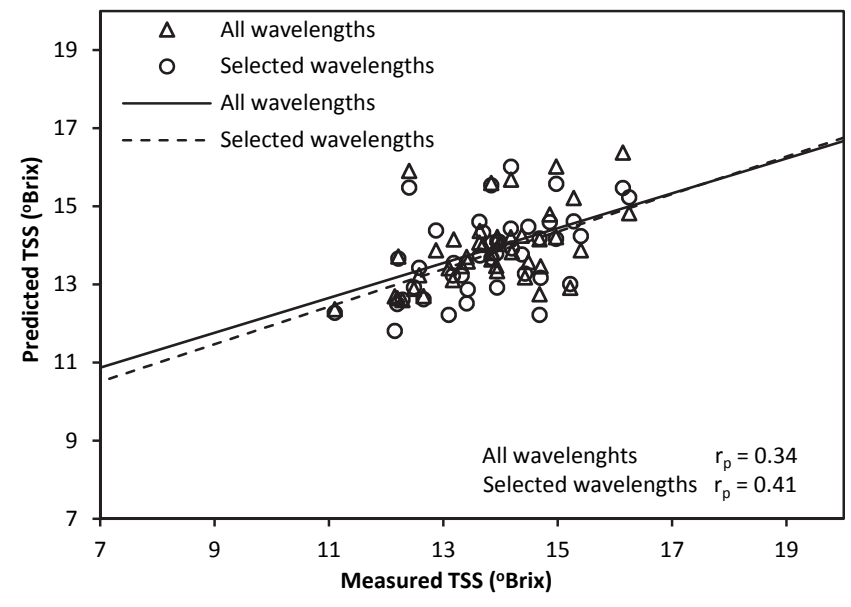

(b)

Figure 6. Measured versus predicted (a) firmness, (b) TSS, (c) $L^{*}$, (d) $a^{*}$, and (e) $b^{*}$ for prediction sets using HSI by PLS regression (continued on next page). 


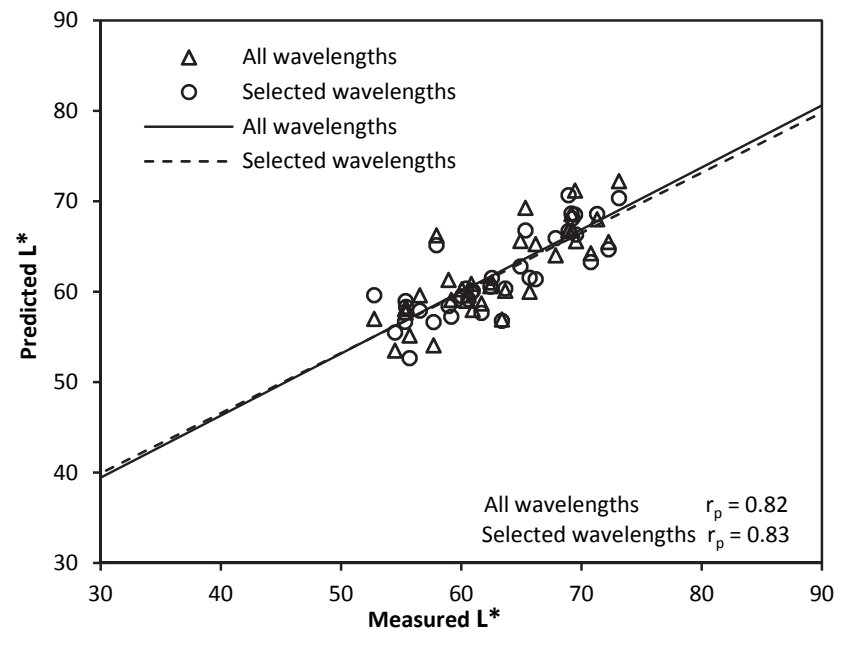

(c)

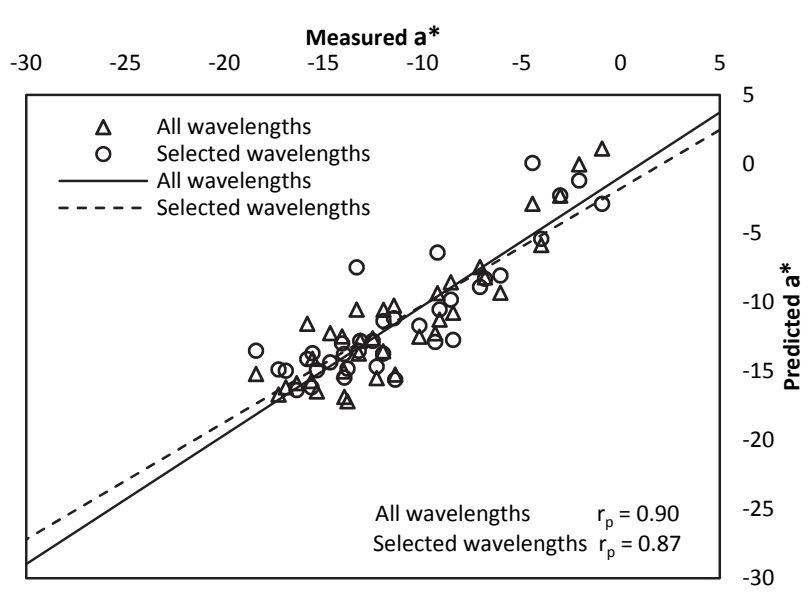

(d)

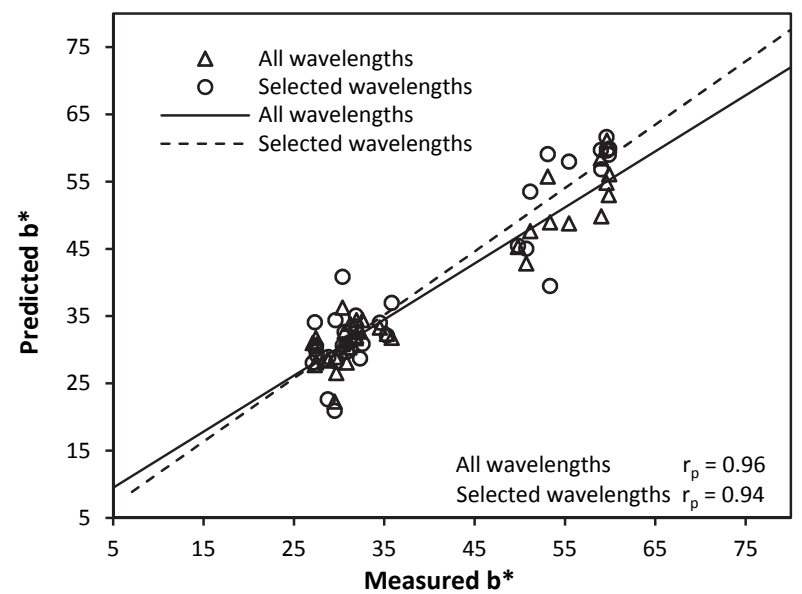

(e)

Figure 6. Measured versus predicted (a) firmness, (b) TSS, (c) $\mathrm{L}^{*}$, (d) a*, and (e) $\mathrm{b}^{*}$ for prediction sets using HSI by PLS regression.

respectively, and $\mathrm{r}_{\mathrm{p}}$ and RMSEP of 0.92 and $4.32(\mathrm{~N})$, respectively), and it was relatively better in predicting the color parameters of apples than the AE technique. In addition, AE performed relatively better than HSI for TSS determination. Because the two methods are based on different measurement principles, they can be complementary; thus, a sensor fusion approach could achieve superior prediction results. These findings can be advantageous for the development of grading and sorting systems for quality control in the handling and marketing of apples.

\section{ACKNOWLEDGEMENTS}

The information reported in this article is part of a project of the Kentucky Agricultural Experiment Station (Paper No. 16-05-094) and is published with the approval of the Director. The authors would also like to thank the USDA for providing partial sponsorship for this research under HatchMultistate Project No. KY005042. We also thank the Iran Ministry of Science and Technology and the University of Tehran for financial support of the scholar who worked on the project.

\section{REFERENCES}

Baietto, M., \& Wilson, A. (2015). Electronic-nose applications for fruit identification, ripeness, and quality grading. Sensors, 15(1), 899. https://doi.org/10.3390/s150100899

Blasco, J., Aleixos, N., \& Moltó, E. (2003). Machine vision system for automatic quality grading of fruit. Biosyst. Eng., 85(4), 415423. http://dx.doi.org/10.1016/S1537-5110(03)00088-6

Butz, P., Hofmann, C., \& Tauscher, B. (2005). Recent developments in noninvasive techniques for fresh fruit and vegetable internal quality analysis. J. Food Sci., 70(9), R131R141. https://doi.org/10.1111/j.1365-2621.2005.tb08328.x

Crosby, J. A., Janick, J., Pecknold, P. C., Goffreda, J. C., \& Korban, S. S. (1994). 'Gold Rush' apple. HortScience, 29(7), 827-828.

Cybulska, J., Pieczywek, P. M., \& Zdunek, A. (2012). The effect of $\mathrm{Ca}^{2+}$ and cellular structure on apple firmness and acoustic emission. European Food Res. Tech., 235(1), 119-128. https://doi.org/10.1007/s00217-012-1743-6

Dong, J., \& Guo, W. (2015). Nondestructive determination of apple internal qualities using near-infrared hyperspectral reflectance imaging. Food Anal. Methods, 8(10), 2635-2646. https://doi.org/10.1007/s12161-015-0169-8

Ekramirad, N., Adedeji, A. A., \& Alimardani, R. (2016). A review of non-destructive methods for detection of insect infestation in fruits and vegetables. Innov. Food Res., 2(1), 6-12.

El Khaled, D., Novas, N., Gazquez, J., Garcia, R., \& ManzanoAgugliaro, F. (2015). Fruit and vegetable quality assessment via 
dielectric sensing. Sensors, 15(7), 15363. https://doi.org/10.3390/s150715363

ElMasry, G., Wang, N., ElSayed, A., \& Ngadi, M. (2007). Hyperspectral imaging for nondestructive determination of some quality attributes for strawberry. J. Food Eng., 81(1), 98-107. http://dx.doi.org/10.1016/j.jfoodeng.2006.10.016

FAOSTAT. (2013). World apple production. Rome, Italy: United Nations FAO. Retrieved from http://www.fao.org/faostat/en/\#home.

Hatcher, D. W. (2008). Chapter 21: Image analysis of oriental noodles. In D.-W. Sun (Ed.), Computer vision technology for food quality evaluation (pp. 523-544). Amsterdam, The Netherlands: Academic Press. https://doi.org/10.1016/B978012373642-0.50024-7

Hernandez-Sánchez, N., Hills, B. P., Barreiro, P., \& Marigheto, N. (2007). An NMR study on internal browning in pears. Postharvest Biol. Tech., 44(3), 260-270. http://dx.doi.org/10.1016/j.postharvbio.2007.01.002

Huang, H., Liu, L., \& Ngadi, M. (2014). Recent developments in hyperspectral imaging for assessment of food quality and safety. Sensors, 14(4), 7248. https://doi.org/10.3390/s140407248

Ikeda, T., Choi, P.-K., Ishii, T., Arai, I., \& Osawa, M. (2015). Firmness evaluation of watermelon flesh by using surface elastic waves. J. Food Eng., 160, 28-33. https://doi.org/10.1016/j.jfoodeng.2015.03.020

Jiménez, A. M., Sierra, C. A., Rodríguez-Pulido, F. J., GonzálezMiret, M. L., Heredia, F. J., \& Osorio, C. (2011). Physicochemical characterisation of gulupa (Passiflora edulis Sims. fo edulis) fruit from Colombia during the ripening. Food Res. Intl., 44(7), 1912-1918. http://dx.doi.org/10.1016/j.foodres.2010.11.007

Leiva-Valenzuela, G. A., Lu, R., \& Aguilera, J. M. (2013). Prediction of firmness and soluble solids content of blueberries using hyperspectral reflectance imaging. J. Food Eng., 115(1), 91-98. http://dx.doi.org/10.1016/j.jfoodeng.2012.10.001

Li, J., Huang, W., Zhao, C., \& Zhang, B. (2013). A comparative study for the quantitative determination of soluble solids content, $\mathrm{pH}$, and firmness of pears by vis/NIR spectroscopy. J. Food Eng., 116(2), 324-332. http://dx.doi.org/10.1016/j.jfoodeng.2012.11.007

Liu, W., \& Hui, G. (2015). Kiwi fruit (Actinidia chinensis) quality determination based on surface acoustic wave resonator combined with electronic nose. Bioengineered, 6(1), 53-61. https://doi.org/10.1080/21655979.2014.996430

Louw, E. D., \& Theron, K. I. (2010). Robust prediction models for quality parameters in Japanese plums (Prunus salicina L.) using NIR spectroscopy. Postharvest Biol. Tech., 58(3), 176-184. http://dx.doi.org/10.1016/j.postharvbio.2010.07.001

Lu, R. (2003). Detection of bruises on apples using near-infrared hyperspectral imaging. Trans. ASAE, 46(2), 523-530. https://doi.org/10.13031/2013.12941

Lu, R., \& Peng, Y. (2006). Hyperspectral scattering for assessing peach fruit firmness. Biosyst. Eng., 93(2), 161-171. http://dx.doi.org/10.1016/j.biosystemseng.2005.11.004

Lu, R., \& Peng, Y. (2007). Development of a multispectral imaging prototype for real-time detection of apple fruit firmness. Opt. Eng., 46(12), 123201-123201-8. https://doi.org/10.1117/1.2818812

Ma, J., Sun, D.-W., Qu, J.-H., Liu, D., Pu, H., Gao, W.-H., \& Zeng, X.-A. (2016). Applications of computer vision for assessing quality of agri-food products: A review of recent research advances. Crit. Rev. Food Sci. Nutr., 56(1), 113-127. https://doi.org/10.1080/10408398.2013.873885

Mazhar, M., Joyce, D., Cowin, G., Brereton, I., Hofman, P., Collins, R., \& Gupta, M. (2015). Non-destructive 1H-MRI assessment of flesh bruising in avocado (Persea americana M.) cv. Hass.
Postharvest Biol. Tech., 100, 33-40.

http://dx.doi.org/10.1016/j.postharvbio.2014.09.006

McGlone, V. A., Jordan, R. B., \& Martinsen, P. J. (2002). Vis/NIR estimation at harvest of pre- and post-storage quality indices for 'Royal Gala' apple. Postharvest Biol. Tech., 25(2), 135-144. http://dx.doi.org/10.1016/S0925-5214(01)00180-6

Mendoza, F., Lu, R., Ariana, D., Cen, H., \& Bailey, B. (2011). Integrated spectral and image analysis of hyperspectral scattering data for prediction of apple fruit firmness and soluble solids content. Postharvest Biol. Tech., 62(2), 149-160. http://dx.doi.org/10.1016/j.postharvbio.2011.05.009

Mizrach, A., Flitsanov, U., Akerman, M., \& Zauberman, G. (2000). Monitoring avocado softening in low-temperature storage using ultrasonic measurements. Comput. Electron. Agric., 26(2), 199207. http://dx.doi.org/10.1016/S0168-1699(00)00072-7

Morrison, D. S., \& Abeyratne, U. R. (2014). Ultrasonic technique for non-destructive quality evaluation of oranges. J. Food Eng., 141, 107-112. http://dx.doi.org/10.1016/j.jfoodeng.2014.05.018

Nanyam, Y., Choudhary, R., Gupta, L., \& Paliwal, J. (2012). A decision-fusion strategy for fruit quality inspection using hyperspectral imaging. Biosystems Eng., 111(1), 118-125. http://dx.doi.org/10.1016/j.biosystemseng.2011.11.004

Nicolaï, B. M., Beullens, K., Bobelyn, E., Peirs, A., Saeys, W., Theron, K. I., \& Lammertyn, J. (2007). Nondestructive measurement of fruit and vegetable quality by means of NIR spectroscopy: A review. Postharvest Biol. Tech., 46(2), 99-118. http://dx.doi.org/10.1016/j.postharvbio.2007.06.024

Parmar, R. R., Jain, K. R., \& Modi, C. K. (2011). Unified approach in food quality evaluation using machine vision. In A. Abraham, J. L. Mauri, J. F. Buford, J. Suzuki, \& S. M. Thampi (Ed.), Proc. Intl. Conf. Advances in Computing and Communications, Part III (pp. 239-248). Berlin, Germany: Springer. https://doi.org/10.1007/978-3-642-22720-2_24

Peng, Y., \& Lu, R. (2005). An improved multispectral imaging system for apple fruit firmness prediction. ASAE Paper No. 056172. St. Joseph, MI: ASAE. https://doi.org/10.13031/2013.19848

Pissard, A., Fernandez Pierna, J. A., Baeten, V., Sinnaeve, G., Lognay, G., Mouteau, A., Dupont, P., Rondia, A., \& Lateur, M. (2013). Non-destructive measurement of vitamin C, total polyphenol, and sugar content in apples using near-infrared spectroscopy. J. Sci. Food Agric., 93(2), 238-244. https://doi.org/10.1002/jsfa.5779

Pu, Y. Y., Feng, Y.-Z., \& Sun, D. W. (2015). Recent progress of hyperspectral imaging on quality and safety inspection of fruits and vegetables: A review. Comp. Rev. Food Sci. Food Saf., 14(2), 176-188. https://doi.org/10.1111/1541-4337.12123

Rady, A., Guyer, D., \& Lu, R. (2015). Evaluation of sugar content of potatoes using hyperspectral imaging. Food Bioproc. Tech., 8(5), 995-1010. https://doi.org/10.1007/s11947-014-1461-0

Rajkumar, P., Wang, N., Eimasry, G., Raghavan, G. S. V., \& Gariepy, Y. (2012). Studies on banana fruit quality and maturity stages using hyperspectral imaging. J. Food Eng., 108(1), 194200. http://dx.doi.org/10.1016/j.jfoodeng.2011.05.002

Rungpichayapichet, P., Mahayothee, B., Nagle, M., Khuwijitjaru, P., \& Müller, J. (2016). Robust NIRS models for non-destructive prediction of postharvest fruit ripeness and quality in mango. Postharvest Biol. Tech., 111, 31-40.

http://dx.doi.org/10.1016/j.postharvbio.2015.07.006

Savenije, B., Geesink, G. H., van der Palen, J. G., \& Hemke, G. (2006). Prediction of pork quality using visible/near-infrared reflectance spectroscopy. Meat Sci., 73(1), 181-184. http://dx.doi.org/10.1016/j.meatsci.2005.11.006

Schoeman, L., Williams, P., du Plessis, A., \& Manley, M. (2016). $\mathrm{X}$-ray micro-computed tomography $(\mu \mathrm{CT})$ for non-destructive characterisation of food microstructure. Trends Food Sci. Tech., 
47, 10-24. http://dx.doi.org/10.1016/j.tifs.2015.10.016

Suykens, J. A., De Brabanter, J., Lukas, L., \& Vandewalle, J. (2002). Weighted least squares support vector machines: Robustness and sparse approximation. Neurocomputing, 48(1), 85-105. http://dx.doi.org/10.1016/S0925-2312(01)00644-0

Wang, H., Peng, J., Xie, C., Bao, Y., \& He, Y. (2015). Fruit quality evaluation using spectroscopy technology: A review. Sensors, 15(5), 11889-11927. https://doi.org/10.3390/s150511889

Wang, S., Huang, M., \& Zhu, Q. (2012). Model fusion for prediction of apple firmness using hyperspectral scattering image. Comput. Electron. Agric., 80, 1-7. http://dx.doi.org/10.1016/j.compag.2011.10.008

Winisdorffer, G., Musse, M., Quellec, S., Devaux, M.-F., Lahaye, M., \& Mariette, F. (2015). MRI investigation of subcellular water compartmentalization and gas distribution in apples. Mag. Reson. Imaging, 33(5), 671-680. https://doi.org/10.1016/j.mri.2015.02.014

Xiaobo, Z., Jiewen, Z., \& Yanxiao, L. (2010). Objective quality assessment of apples using machine vision, NIR spectrophotometer, and electronic nose. Trans. ASABE, 53(4), 1351-1358. https://doi.org/10.13031/2013.32572

Yu, J. T., Ding, M. L., \& Wang, Q. (2011). Linear location of acoustic emission source based on LS-SVR and NGA. Appl. Mech. Materials, 80, 302-306.

https://doi.org/10.4028/www.scientific.net/AMM.80-81.302

Zhu, Q., Huang, M., Zhao, X., \& Wang, S. (2013). Wavelength selection of hyperspectral scattering image using new semisupervised affinity propagation for prediction of firmness and soluble solid content in apples. Food Anal. Methods, 6(1), 334342. https://doi.org/10.1007/s12161-012-9442-2

Zude, M., Herold, B., Roger, J.-M., Bellon-Maurel, V., \& Landahl, S. (2006). Non-destructive tests on the prediction of apple fruit flesh firmness and soluble solids content on tree and in shelf life. J. Food Eng., 77(2), 254-260.

http://dx.doi.org/10.1016/j.jfoodeng.2005.06.027 